\title{
Zevallos Aguilar, U. J. (2018). Literatura y cultura en el sur andino. Cusco Puno (siglos XX y XXI). Cusco, Perú: \\ Ministerio de Cultura del Perú. 281 pp.
}

\author{
Beatriz Rodríguez \\ ORCID: https://orcid.org/0000-0002-2467-3408 \\ charlote462@hotmail.com
}

Seguir buscando la reforma del Perú desde una perspectiva eurocentrista no hace sino develar nuestra mentalidad colonial, impidiéndonos escuchar y comprender las voces que hablan por sí mismas, sin necesidad de "antiparras yanquis o francesas"1. Precisamente el libro Literatura y cultura en el sur andino. Cusco-Puno (siglos XX y XXI) de Ulises Zevallos Aguilar no solo analiza las más sobresalientes y diversas manifestaciones artísticas y culturales del Cusco y Puno, sino que también formula una revisión crítica en torno a las rebeliones indígenas de los pueblos aymaras, quechuas y sus aliados en el sur andino. Asuntos de diferencia cultural, autoridad social y discriminación política revelan los antagonismos dentro de la "racionalización" de la modernidad. Estos antagonismos se convierten en alternativas dispersas y estrategias empoderadoras de emancipación y democratización. Desde lo local, lo vejado, despojado, dominado, desplazado, migrante y diaspórico revelan una perspectiva enriquecedora plural étnica, en su diversidad cultural de todas las sangres y todas las patrias ${ }^{2}$.

Esta investigación contribuye a entender, rescatar y difundir la genealogía de los estudios andinos desde una perspectiva socioeconómica y una visión transformadora. Permite generar cambios y dar respuesta a las reivindicaciones sociales tan urgentes y necesarias para el mundo andino, las cuales han sido postergadas con la violencia del colonialismo, relegitimada en el republicanismo y perversamente prolongada en la república. Anclada en su sistema centralista de privilegios de las élites y agonizante en sus marginaciones y despojamientos económicos. Antonio Cornejo Polar y Mario Benedetti invocaron el requerimiento de fundar una crítica verdadera latinoamericana y la necesidad de autointerpretarse ${ }^{3}$, precisamente este libro rechaza la visión lineal de los procesos literarios, históricos y de los encasillamientos genéricos para destacar su enfoque multidisciplinario examinando las expresiones culturales no canónicas y canónicas de las periferias 
internas de orígenes aimaras y quechuas en el Perú. Así reivindica los cimientos de una literatura más auténtica.

Literatura y cultura en el sur andino. Cusco-Puno (siglos XX y XXI) de Ulises Zevallos Aguilar consta de dos partes de once capítulos en total, con una introducción al principio y una entrevista del propio autor al final del libro. La primera parte contiene seis capítulos. Como el autor mismo lo señala son las ilustraciones a cuestiones generales. En ellos examina y formula conceptos como las culturas periféricas internas en la región andina, la otra vanguardia, el modernismo, archipiélagos transandinos y representantes del regionalismo crítico. En la segunda parte se enfoca en las obras de los autores ya referidos, descubriendo múltiples registros critico-histográficos, y estéticos mientras recorre desde el cuento, ensayo, novela, poesía, testimonio, revista cultural, fotografía y otras formas de arte.

El primer capítulo: "Culturas de las periferias internas en la región andina. El grupo Orkopata (1926-1930)”, es el estudio del grupo formado por poetas, narradores, ensayistas, educadores, dramaturgos, músicos puneños. $\mathrm{Su}$ estrategia fue apropiarse del espacio hegemónico, desde la periferia interna para manifestar su discurso alternativo, heterogéneo y democratizador. Es interesante constatar como los estudios subalternos albergan la potencialidad de responder a la pregunta: cómo vivir juntos y su planteamiento resulta vital para erradicar el centralismo y las ideologías que obstaculizan alternativas de progreso que significan el avance para el Perú. El grupo Orkopata se inscribe dentro del contexto del periodo de la primera modernización en el Perú con el gobierno de Augusto B. Leguía (1919-1930) y su eslogan "Patria Nueva", con los proyectos nacionales legitimadores de la ideología universal. Continuaba el patrón hegemónico del sistema colonial, en donde el poder era ejercido según la superioridad biológica racial, de señores que dominaban a mestizos e indios. Estos intelectuales de clase media desde la periferia interior transformaron el discurso homogéneo de las elites capitalinas, representaron su región y los intereses de su población quechua y aimara creando proyectos en la educación rural. Establecieron conexiones nacionales e internacionales con otros centros culturales y reivindicaron la cultura autóctona andina. "La otra vanguardia: Propuesta de edición de revistas vanguardistas peruanas (1920-1930)" presenta una recopilación de las Empresas editoras en el Perú, cuyos focos de publicación, difusión y conexión artística y cultural fueron en Lima, Cusco, Puno y Arequipa. Contribuyeron en la formación y conexión del archipiélago vanguardista, convirtiéndose en una auténtica vanguardia latinoamericana pero que es menos estudiada y se deterioró a través de 
los años por figurar en la lista de las vanguardias no canónicas. El amauta José Carlos Mariátegui fundó la Editorial Minerva en Lima (1925), imprimió las revistas Amauta (1926-1930) y Labor, el periódico obrero Labor; Tempestad en los Andes (1927) de Luis E. Valcárcel y Los siete ensayos de la realidad peruana (1928) de José Carlos Mariátegui. Otras editoriales en Lima son La Sierra (1926). En el sur andino: Editorial Titikaka (1926).

"Automóviles, indigenismo y racismo en el Perú del siglo XX. De máquinas de progreso a máquinas asesinas" tiene como objetivo abrir cuestiones acerca de las implicancias de la "máquinas" de antes y el ahora. Es decir, de la primera modernización capitalista iniciada por Augusto B. Leguía (1919-1930) y la segunda neoliberal emprendida con el presidente Fernando Belaunde Terry (19801984) y los presidentes que continuaron hasta nuestros días. Si en la República, afirma José Carlos Mariátegui, en lugar de mejorar las condiciones del indígena se había exasperado su miseria, en la época neoliberal apunta Zevallos Aguilar se ha desatado un genocidio legal al desterritorializarlo/a y sobreexplotar sin medida su espacio y sus cuerpos. Este sistema de explotación y de racismo es un problema fundamental que viene funcionando desde el siglo XVI para el control mundial del poder. ¿Cómo es posible que ahora exista más racismo que en la primera ola de la modernización en 1920 ?

Con el objetivo de discutir y avanzar en la elaboración de los conceptos previamente discutidos, se introducen en este capítulo tres sujetos sociales que representan la estética vanguardista aimara y quechua: "Martin Chambi, Gregorio Condori Mamani y Alejandro Peralta. Propuestas de modernidad alternativa en el sur peruano (1900-1930)". La fotografía realista del cusqueño Chambi; la Autografía de Gregorio Condori Mamani, testimonio escrito por los antropólogos cusqueños Ricardo Valderrama y Carmen Escalante y el poemario del puneño Alejandro Peralta. Estas obras tuvieron diferentes perspectivas sociales, fueron protagonistas de la modernización de los años veinte y se apropiaron de la tecnología para revelar la ferocidad del capitalismo en la periferia interna, proponiendo otras opciones artísticas, sociales y culturales a la modernidad. Ellos encarnan "los mejores proyectos de la modernización alternativa que son poco estudiados y conocidos por generarse en las periferias" (90). En esta sección, particularmente loable: "Gamaliel Churata, José María Arguedas y Luis Figueroa. La constitución del regionalismo crítico en el Perú en el siglo XX”, Zevallos sostiene que las obras de Churata, Arguedas y Figueroa, "inician una corriente artística de regionalismo crítico en el Perú" (95). Además, "establecieron un punto de quiebre en la 
trayectoria de la literatura y cine peruanos. Sus lenguajes de ruptura, mezclas de lenguas e imaginarios aymara, quechua y castellano; así como la fragmentariedad de su estructura, transgresión de géneros literarios y fílmicos y la combinación de autobiografía y ficción, plantearon serios desafíos a su inmediata interpretación" (94). Los tres maestros peruanos, descendientes del sur andino, son regionalistas porque palmaron en sus letras la diversidad y complejidad cultural y humana de las localidades en que habitaban. Estos maestros no fueron indiferentes a su comunidad, por lo contrario, resguardaron y valoraron con efusión las culturas locales aymara y quechua que han sido omitidas por el Estado peruano centralista, desbarataron la narrativa oficial que había construido estereotipos para justificar su control y dominación de la población indígena, planteando otras alternativas de regionalización. "Archipiélagos transandinos. Hacia una nueva cartografía de la transformación cultural”, trata sobre la genealogía de los estudios trasandinos y los estudios efectuados en el ámbito internacional como nacional. Se examinó las identidades andinas en un ámbito de migraciones masivas por imposición del neoliberalismo que causó más crisis económica y el conflicto armado. Se identificó diversos discursos identitarios en proceso. Asimismo, se observa su capacidad de adaptación y éxito en el extranjero por su identidad andina como prácticas sociales de la familia extendida, las relaciones comunitarias, formas de reciprocidad y el bilingüismo los cuales facilitaron su adaptación en el exilio.

La segunda parte se inicia con el análisis en: "Compresión de tiempo/ espacio y modernidad alternativa en Cinco metros de poemas (1927) de Carlos Oquendo de Amat". Su poemario se convirtió en una de las obras que iniciaron la corriente vanguardista en el país. Oquendo produce una poesía innovadora, de imágenes provocadoras e irónicas a partir de una libertad creadora que no deja de estar exenta de una conexión social profunda. El poeta propone una modernidad alternativa en el ámbito poético, criticando "un sistema de producción que se basa en la estandarización masiva y el uso de la línea de ensamblaje" (141). De esta forma, representa el fenómeno de la compresión de tiempo y espacio que son elementos claves del desarrollo del mundo capitalista moderno. Oquendo de Amat critica la modernidad capitalista que ha visto y ha sido testigo en sus viajes debido a su exilio político, proponiendo: "la modernidad alternativa que se encuentra en la materialidad y contenido del libro", (150) basada en los valores de las culturas locales. "Hacia una lectura intermedial y decolonial de Resurrección de los muertos (2011) de Gamaliel Churata" responde a la epistemología europea y 
a las campañas colonizadoras para destruir, evangelizar y desterritorializar al poblador andino, considerándola una raza inferior. Zevallos anota que Churata fue un innovador de la teoría decolonial, ya que incorpora en su narrativa ontologías, cosmovisiones y epistemología indígenas. Además, la literatura, la música, la danza y los testimonios fueron medios que él creó para difundir, entretener, educar y comunicar a diversas poblaciones, realizando un esfuerzo democratizador en el cual incluía la urbe aimara y quechua. En este sentido, Churata pone en vigencia el credo vanguardista que buscaba la reforma política y artística. De esta manera, se acercó a lo popular, los aimaras y quechuas en su propuesta cultural y narrativa para incluir al Estado nación, en un proceso de "reterritorilización”. "Kukuli (1961) y el cine andino de Luis Figueroa (1928-2012)”, muestra la diversidad de la flora, la fauna, y una naturaleza de variantes múltiples pisos ecológicos con espacios rurales y urbanos del sur peruano andino. Su propuesta ideológica estética según Zevallos es el regionalismo crítico, la cual se oponía a la propuesta moderna capitalista. El proyecto modernizador consistía en explotar el espacio andino y desaparecer el obstáculo del avance, la cultura indígena. Revela vigentes valores y tradiciones quechuas de una forma creativa mientras se apropia de elementos españoles desde el siglo XVI, creando pastiches, metaficción e ilustrando su estilo reformador y precursor del postmodernismo.

"La literatura testimonial del sur andino. Saturnino Huillca (1974), Gregorio Condori Mamani (1977), Mariano Larico Yujra (1990) e Hilaria Supa Huamán (2001)" son obras claves testimoniales que constituyen textos políticos y etnográficos en la época precedente y posterior a la reforma agraria del gobierno del general Juan Alvarado (1968-1975), y los gobiernos llamados democráticos que le siguieron. Remarcamos los testimonios femeninos de la esposa de Gregorio Condori, Asunta Quispe Huamán (1977) e Hilaria Supa Huamán (2001), quienes en su testimonio desmantelan los estereotipos que se tienen sobre las mujeres quechuas como personas pasivas y victimas de sus opresores. Sus memorias nomádicas abordan a un texto paradójico y complejo representando a la indígena andina en su condición de doble subalternidad (subalterna de su esposo en un contexto de periferia interna), y en un escenario marginal, en donde su única opción es el nomadismo ya que debe huir de espacio a espacio para sobrevivir. En sus andanzas para subsistir, su cuerpo es inscrito como objeto para explotar, discriminar y humillar. Sin embargo en este lugar de dobleces y contradicciones, recopila la tragedia nacional para transformarla desde un estado de dolor y marginalización hacia un ámbito de solidaridad y poder. 
En el último capítulo, "Poesía cuzqueña quechua última, movimientos sociales y neoliberalismo (1980-2009)”, encontramos el rescate de la poesía en quechua de los escritores Odi Gonzales y Ch'aska Anka Ninawaman. Señala Zevallos señala que la construcción de la narrativa quechua se lleva a cabo en el género poético. En este sentido, la narrativa quechua compuesta de la tradición oral se encuentra más cercana a la poesía, ya que se puede ser recitada y no leída. De esta forma, se convierte en una herramienta que sirve de difusión para una numerosa audiencia que tendría la potencialidad de ser: "una de las expresiones más significativas de los sectores andinos". Se termina el libro con una entrevista al autor por el escritor Luis Nieto Degregori, en donde Zevallos explica su trayectoria de investigación a partir de los diversos indigenismos periféricos regionales hasta sus manifestaciones desde un contexto global. Asimismo, señala la importancia del incesante movimiento indígena y su dinámica, el indigenismo y la persistencia de las relaciones disímiles con la población indígena a través de los siglos.

En su conjunto, este libro está concebido como un mecanismo de legitimación que abarca las más iluminadoras reproducciones artísticas culturales de la formación peruana desde la periferia interna del sur andino desde principios del siglo XX hasta nuestros días. Zevallos Aguilar no solo analiza, formula y recalca la importancia de la publicación de ediciones críticas de revistas vanguardistas y ediciones críticas, sino que también innova los esquemas instituidos por los grupos dominantes, sobre las cumbres de la vanguardia canónica para develar una auténtica literatura peruana. Los narradores Gamaliel Churata, José María Arguedas, Luis Figueroa, Carlos Oquendo de Amat, los testimonios de Gregorio Condori Mamani, Asunta Quispe Huamán, Huillca, Larico Yujra, Hilaria Supa Huamán y la poesía contemporánea de Gonzales y Ch’aska Anka Ninawaman ubican su producción de cara a las contradicciones de la modernidad capitalista fundacional, lo hacen a partir de una conciencia de una sociedad desmembrada en su constitución sociocultural, donde confluyen distintas culturas, con sus múltiples lenguas dentro de un marco homogeneizador y centralista que excluye cualquier papel activo de la presencia indígena en el Perú del futuro. En este sentido la obra aborda más precisa, la construcción de nuevas subjetividades y perspectivas políticas aimaras y quechuas tomando en cuenta procesos de descolonización del poder, del saber y género, aspirando a originar una verdadera innovación cultural, siendo conscientes de la realidad del Perú. 


\section{Notas}

1 José Martí señaló en su ensayo Nuestra América (1891).

2 José María Arguedas se refirió al conflicto entre la nación peruana multicultural: su autonomía socioeconómica, su legado histórico indígena por un lado y el poder económico que impone la explotación despiadada de los recursos naturales y humanos.

3 En "El indigenismo y las literaturas heterogéneas: su doble estatuto socio-cultural" (Antonio Cornejo Polar).

\section{Bibliografía}

Zevallos Aguilar, U. (2018). Literatura y cultura en el sur andino. Cusco-Puno (siglos XX y XXI). Qillqa Mayu.

Cornejo Polar, Antonio. (1978). El indigenismo y las literaturas heterog neas: su doble estatuto socio-cultural. Revista de Crítica Literaria Latinoamericana. IV(7-8), 7-21

Martí, J. (1989) Politica de nuestra américa. Siglo XXI.

\section{Biodata}

Carla Beatriz Rodriguez Bulnes, es catedrática en Historia Subalterna y Lenguas en Grand Canyon University y otras universidades en Maricopa. Bachiller en Ciencias Políticas de la Universidad de California y máster en Literatura Latinoamericana. Doctorado en Literatura Latinoamericana de Arizona State University. Especialización en Narrativa Testimonial, Estudios Subalternos, Geográficos y Feminismo. Interés de investigación: literatura de la diáspora, la migración y transfronterizos. Ha publicado: "Testimonio en la narrativa de la guerra en Perú", "La representación del inmigrante rural femenino subalterno indígena", "César Moro y el surrealismo", "'Agua' y el derecho a la vida a través del praxis indígena y la destrucción ambiental” y otros artículos. 